\title{
Policies and practices of early childhood education and care during the COVID-19 pandemic: Perspectives from five countries
}

\author{
Adrijana Visnjic-Jevtic ${ }^{1}$, Anikó Varga $\mathrm{Nagy}^{2}$, Gulsah Ozturk ${ }^{3}$, ikbal Tuba Şahin-Sak ${ }^{4}$, Jesús \\ Paz-Albo ${ }^{5}$, Mehmet Toran ${ }^{6}$, Noelia Sánchez-Pérez ${ }^{7}$
}

\begin{abstract}
The COVID-19 pandemic, which affects all areas of life, has also affected children in need of education and care. It is of great importance to develop policies that take into account the best interests of children in this process. In this review article, the policies developed for early childhood education and care during the pandemic period in five countries (Australia, Croatia, Hungary, Spain, and Turkey), how they are implemented, the problems that arose, and the solutions produced are discussed. As a result, the COVID-19 pandemic has revealed that we need to focus on eliminating the educational inequalities, set policies for the welfare of children on foundations that are more realistic, rebuild teacher training, and improve the welfare of families. Priorizating the best interests of the child in the policies to be developed and building the social ecology on justice will ease overcoming the crises that will be faced.
\end{abstract}

\section{Article History}

Received: 24 May 2021

Accepted: 14 July 2021

\section{Keywords}

COVID-19; Pandemic, Early

childhood education and

care; Policy; Practice;

Children; Parents; Teachers

\section{Introduction}

Early childhood education and care (ECEC) forms the basis for the acquisition of lifelong competencies. The disadvantages of children who cannot access a qualified environment and education in the early years continue throughout their lives, and to overcome this, practices that consider the best interests of all children should be a priority in the country's policies. According to United Nations Children's Emergency Fund (UNICEF) reports, it is stated that 175 million children between the ages of 36 do not benefit from early childhood education at all, and one out of every four children who is one year younger than the compulsory education age does not benefit from early childhood education at all (UNICEF, 2021a). Moreover, these are data prior to the COVID-19 pandemic and it is not yet known how children are affected by early childhood education as the pandemic continues. However, according to UNICEF's estimates, the global economic crisis caused by the pandemic negatively affected families in developing countries, and it is estimated that the number of poor children could exceed 725 million, with 142 million more children already facing poverty (UNICEF, 2021b). Undoubtedly, the increase in poverty leads to the restriction of children's access to education and health, and to a decrease in healthy nutrition resources. Furthermore, poverty causes parents to face difficulties in creating economic resources and experience psychological problems, and it disrupts family dynamics. This poverty not only directly affects the family and the child, but also negatively affects the budget allocated by the countries for education, which is an indicator of social welfare. This negative effect on the education budget causes interruptions or a decrease in the quality of the education services provided. Economically, psychologically, and

\footnotetext{
${ }^{1}$ University of Zagreb, Faculty of Teacher Education, Zagreb, Croatia, e-mail: adrijana.vjevtic@ufzg.hr, ORCID: https://orcid.org/0000-0003-3812-7472

2 University of Debrecen, Faculty of Education for Children and Special Educational Needs, Debrecen, Hungary, e-mail: vnaniko@ped.unideb.hu, ORCID: https://orcid.org/0000$\underline{0001-5868-3156}$

${ }^{3}$ Deakin University, Faculty of Arts and Education, Melbourne, Australia, e-mail: gulsah.ozturk@deakin.edu.au, ORCID: https://orcid.org/0000-0001-5243-3172

4 Van Yüzüncü Yıl University, Faculty of Education, Van, Turkey, e-mail: ikbalsak@yyu.edu.tr, ORCID: https://orcid.org/0000-0002-9054-6212

${ }^{5}$ Rey Juan Carlos University, Faculty of Legal and Social Sciences, Madrid, Spain, e-mail: jesus.pazalbo@urjc.es, ORCID: https://orcid.org/0000-0001-7517-7124

${ }^{6}$ Istanbul Kultur University, Faculty of Education, Istanbul, Turkey, e-mail: m.toran@iku.edu.tr, ORCID: https://orcid.org/0000-0003-3457-9113

${ }^{7}$ University of Zaragoza, Faculty of Social and Human Sciences, Teruel, Spain, e-mail: noeliasanchez@unizar.es, ORCID: https://orcid.org/0000-0002-6112-9639
} 
sociologically fragile societies are facing major crises in this sense, along with the pandemic.

As a result of the rapid spread of the pandemic and became life-threatening, schools at all levels were closed in 191 countries, and 1.7 billion students continued their education based on the policies and practices that were promptly developed by their countries (United Nations Educational, Scientific and Cultural Organization [UNESCO], 2021) in line with the policies to combat the pandemic (World Health Organization [WHO], 2020) announced by the WHO on March 11, 2020. According to the report prepared by UNICEF in September 2020, while the rate of countries that switched to distance education at primary and post-secondary levels was $90 \%$, this rate was $60 \%$ in early childhood education (UNICEF, 2021c). In the report, it is stated that despite these rates, not all children have equal access to education, educational inequality has become more evident with the pandemic, teachers' technology literacy and competent use are low in underdeveloped and developing countries, and there are difficulties in providing and accessing digital tools (UNESCO, 2020).

The fact that inequality in access to ECEC has become apparent during the pandemic is due to the policy uncertainties and investing in ECEC not being a priority. In addition, the suspension of education of $40 \%$ of children benefiting from early childhood education because of the pandemic (UNICEF, 2021c) contains important clues that larger crises will occur. These clues make it important to evaluate the educational policies and practices of the authorities during the COVID-19 pandemic. In this review article, the policies developed for ECEC during the pandemic in five countries (Australia, Croatia, Hungary, Spain, and Turkey), how they were implemented, the problems that arose, and the solutions produced were discussed.

\section{Australia: Policies and Practices of ECEC during the COVID-19 Pandemic}

In Australia, ECEC services comprise child care and preschool services. They provide education and care for over 1.3 million children (Department of Education, Skills and Employment [DESE], 2020a). Types of ECEC programs include long day-care (often called Early Learning Centres), family day-care services, and preschools. Children's attendance to an ECEC program in the pre-school year is not compulsory. However, since 2008 the Australian Government has committed to universal access to ECEC in the year before full-time schooling (Parliament of Australia, 2014).

The first case of COVID-19 in Australia was recorded on 25 January 2020 and it was linked to an overseas traveler from China. As the number of daily COVID-19 cases increased steadily over the following weeks, Australia introduced an international travel ban, border closures, quarantine, high testing rates, rapid case isolation, and contact tracing (McAnulty \& Ward, 2020). On 27 March 2020, the Australian Government declared the ECEC sector 'essential' to the economy (Parliament of Australia, 2020a). That means ECEC services were required to remain open. This declaration highlighted ECEC as a fundamental service for supporting parent participation in the workforce (Thorpe, Staton, Houen, \& Beatton, 2020).

In the early months of the COVID-19 pandemic, the ECEC sector experienced the devastating impact of COVID-19 when the demand for ECEC services declined dramatically. Many families pulled their children out of ECEC services in Australia. Some families unenrolled their children because they could provide care to their children at home due to losing employment or working from home and some families had health concerns (Parliament of Australia, 2020b).

Lockdown restrictions were implemented to monitor the COVID-19 outbreak across the country between late March and mid-May 2020. During the outbreak, the health officials considered ECEC services were essential. These services were able to operate by paying attention to hygiene, physical distancing, cleaning surfaces at least daily (e.g. tables, chairs, light switches) and washing resources such as play items and toys (Early Childhood Australia, 2020). It was suggested that young children were less likely to catch the virus. Families were encouraged to keep their children in ECEC services, while they were given the option to keep their children at home.

In April 2020, the Australian Government announced an Early Childhood Education and Care Relief Package to support families and the ECEC sector. The Relief Package (also referred to as 'free' childcare) 
Policies and practices of early childhood education and care during the COVID-19...

provided $\$ 1.6$ billion to the sector for three months (DESE, 2020b). Families were not charged any fees between April and July 2020. Priority was given to working parents, disadvantaged and vulnerable children who needed to access ECEC (Prime Minister of Australia, 2020c ). In the landscape of Australian ECEC, the Relief Package has been one of the most effective policies to open up a new space for caring for children during a pandemic (Lee, 2021).

The COVID-19 pandemic transformed many practices in ECEC settings. Educators implemented strict hygiene measures which minimized the number of parents during their children's arrival and departure times. Children were dropped off and picked up at the centre entrance to enforce social distancing (Early Childhood Australia, 2020). The reduced contact with parents made educators establishing new forms of communication with them through apps, email or phone.

Many early childhood educators provided regular communication and resources to support families and children who stayed at home through online teaching and learning (Park, Logan, Zhang, Kamigaichi, \& Kulapichitr, 2020). This led to changes in teaching practices including developing digital learning materials to engage with children and supporting families who remained at home. Early childhood educators had to provide play-based educational programs remotely. Some early childhood settings used online portals (e.g. Storypark) or sent newsletters about online resources (e.g. Victorian Government Education and Training). Families could access to 'learning from home' resources for early childhood education on the state departments' website.

In July 2020, the Australian Government has implemented a Transition Package which provided a Transition payment to the ECEC services until the end of September 2020. During this period, except Victoria, attendance to ECEC services returned to pre-COVID levels nationally. ECEC services have been required to have a COVIDSafe plan with risk mitigation measures (i.e. hygiene and health measures).

The COVID-19 pandemic has affected Australian states and territories unevenly. Victoria has been Australia's worst affected state with over $68 \%$ of the COVID-19 cases and $90 \%$ of the deaths that occurred across the country (Department of Health, 2021). Victoria's second lockdown lasted almost four months. During Stage four restrictions in August 2020, ECEC services remained open only for vulnerable children who cannot learn at home and children whose parents work in essential services in Melbourne ${ }^{1}$ [ECEC services remained open to all children in regional Victoria]. This was a major change from Australia's first lockdown period. Many families faced challenges in the closure of ECEC settings. Working parents had to work from home while providing care for their children for approximately 11 weeks. In order to support Victorian ECEC services, the government announced the Recovery Package which provided a \$305.6 million Recovery Payment for Victoria until the end of January 2021 (DESE, 2020b). The aim was to ensure that ECEC services remain open while providing financial support to families. Since November 2020, ECEC settings in Victoria have resumed their regular programs with a COVIDSafe Plan ${ }^{1}$.

The experience of the COVID-19 pandemic shows that ECEC is an essential service for working parents however it is also important to recognise and support ECEC educators who provide this service (Thorpe et al., 2020). During this time, they prioritised the well-being of young children and families. More attention should be given to the experiences of ECEC educators in supporting children and their families.

\section{Croatia: Policies and practices of ECEC during the COVID-19 Pandemic}

ECEC in the Republic of Croatia is not part of the compulsory educational system. The exception is the preschool program intended for children in the year before starting school. The preschool program, lasting 250 hours, is mandatory for school-age children (children aged 6-7, who start primary school in the next school year). It usually takes place in ECEC settings or primary schools if there are no ECEC settings nearby. This position determines how the ECEC system itself and its organization are perceived in public. Although it is a system that is part of the Ministry of Science and Education, aimed to ensure the wellbeing (personal, emotional, physical, educational, and social) of the child (Ministarstvo Znanosti, Obrazovanja i

\footnotetext{
${ }^{1}$ As of $1^{\text {st }}$ of June 2021, Victoria is currently in its fourth lockdown. Primary and secondary schools are currently closed while ECEC remain open.
} 
Sporta [MZOS], 2015), the public more often perceives it as a system for caring for children so that parents can work. This attitude is also promoted by certain projects (for example, Improvement of services for children in the system of early and preschool education) funded by the Ministry of Labor, Pensions, Family and Welfare, which are founded on the idea of social policy (ensuring reconciliation of family and business life). In practice, this means, among other things, providing a kindergarten for all children in accordance with the needs of parents. It is therefore questionable whether this is an idea that is in line with the basic goal of ECEC in the Republic of Croatia - ensuring the well-being of the child.

This position of ECEC in the Republic of Croatia partly determined the attitude towards the openness/closeness of ECEC settings during the COVID-19 pandemic. In mid-March, a pandemic of Covid19 disease was declared (Ministry of Health, 2020), and the Government of the Republic of Croatia (Vlada Republike Hrvatske) (2020) passed a Decision to suspend teaching in higher education, secondary and primary schools and the regular operation of early childhood education institutions. The pandemic resulted in the closure of many institutions, restrictions on movement and, where possible, remote work. The new family and work structure were somehow improvised. Višnjić-Jevtić and Visković (2021) conclude that a new daily rhythm and schedule of activities had to be organized, mutual obligations (jobs, roles) and ways of solving problem situations had to be harmonized. The closure of educational institutions and the transition to a virtual work environment indicated unequal opportunities for participation due to technical and social issues. While lower primary classes were organized through television (School on $3^{r d}$ ) and upper primary and secondary classes were organized through various learning platforms, early childhood education was not organized at the state level. Somolanji Tokić and Vukašinović (2020) find that organization of early childhood education work depended mostly on the intrinsic motivation of teachers, while there wasn't official support from the state. This has led to various solutions - from opening kindergartens for first-line workers, through designing group communication with children and parents on different communication platforms to creating an online kindergarten. Therefore, early childhood education during the pandemic in Croatia faced with several issues: organization of the work; the wellbeing of the children due to digital exposure; digital competencies of teachers; and wellbeing of the teachers. Due to the closure of kindergartens, it was questionable how to organize work for teachers (what they could do when there are no children in the settings) and children (to ensure continuity in education), and at the same time help the parents. Research in Croatia shows that activities organized by ECEC settings for children most often required the joint involvement of children and parents (Višnjić-Jevtić \& Visković, 2021). Parents who continued to go to work had to organize time and space for children, while parents who worked from home had to organize time and space for both - themselves and their children.

In ECEC settings that remain open for first-line workers teachers faced a new way of communicating with parents which made it difficult to support each other. Regarding the well-being of young children, it is questionable whether viral activities contribute to the well-being of a child. The most common challenges of the viral environment for children are the absence of play (Schmitt, Pempek, Kirkorian, Lund, \& Anderson, 2008; Setliff \& Courage, 2011), difficulties in social and emotional functioning of children (Radesky, Schumacher, \& Zuckerman, 2014), slower language development (Mendelsohn et al., 2010; Zimmerman, Christakis, \& Meltzoff, 2007) and insufficient physical activity (Marshall, Biddle, Gorely, Cameron, \& Murdey, 2004). Anderson and Subrahmanyam (2017) point out that the impact of the screen depends on the age of the children, and for children under the age of two it is mostly negative, while for preschool children it has negative and positive aspects. As a result of the above research, it is possible to problematize the organization of ECEC settings through various digital platforms. To organize an appropriate learning environment for young children, ECE teachers should have certain digital competencies. Kim (2020) states that the quality of online learning in early childhood depends in part on the digital competencies of ECE teachers. Somolanji Tokić and Vukašinović (2020) stated that due to the non-mandatory status of ECEC, ECE teachers in Croatia doesn't have the possibility to master their competencies requested in the European Framework for the Digital Competence of Educators: DigCompEdu. Working in changing conditions, which required new competencies, reflected on the wellbeing of ECE teachers. Professional responsibility requires adaptation to new conditions and continuous support for children and parents. On the other hand, many educators are parents themselves which can 
Policies and practices of early childhood education and care during the COVID-19...

pose an organizational challenge to their family life. Given the specificity of work in which it is impossible to ensure distance, educators are also exposed to health risks. In preparation for the reopening of ECEC settings, a Recommendation for working with early and preschool children in kindergartens (Ministarstvo Znanosti i Obrazovanja [MZO], 2020) was adopted, which was to provide guidelines for work after reopening. The recommendation is guided by health and epidemiological guidelines relating to the protection of health in the first place.

A year after, kindergartens are open, but that brings new challenges. The environment that supposed to be enabling, full of possibilities for playing and learning became equipped only with materials that may be disinfected. Therefore, loose parts or natural materials are forbidden just as soft, cuddling toys. The absence of toys and other stimulative material may lead to exploration of a new play(s), and experiences of new learning strategies in cooperation with peers. Unfortunately, play with peers should be organized to avoid close, physical contact and teachers were suggested engaging children in activities that give possibilities of distancing. One of the teachers try to explain the new situations:

New challenges are emerging. Parents do not tell us that they are infectious and bring their children to kindergarten,
despite that. In this way, the trust we have been building for many years is lost. Cooperation with parents has been
reduced to a minimum due to epidemiological measures, and continuity in care and education between family and
institutions is being lost. There isn't continuity in educational work with children due to frequent absences and the
self-isolation of children. Teachers are overworked and exhausted due to frequent sick leave and consequently, the
replacement of sick colleagues (VB, 37 years, ECE teacher).

Working in COVID conditions caused new challenges on many levels. More than a year later, there is no signs or strategies that should help teachers to strengthen children and parents in the new normal.

\section{Hungary: Policies and Practices of ECEC during the COVID-19 Pandemic}

In Hungary, kindergarten education has a long tradition. The first kindergarten opened its doors in 1828, while the first crèche opened in 1852. Since September 2015, attendance to the kindergarten has been compulsory from the age of 3 , the aim of which is to minimise disadvantage and to ensure equal opportunities and life chances for all children.

The disease, referred to as COVID-19, was declared a pandemic by the UN health organization on 11 March 2020 (WHO, 2020). The Hungarian Government created the Operative Staff in order to fight the new coronavirus, their information about official measures appears on koronavirus.gov.hu website. The Hungarian Government (Government Decree 40/2020) declared an emergency situation for the entire territory of Hungary in order to prevent the consequences of a human pandemic causing a mass illness endangering the safety of life and property and to protect the health and life of Hungarian citizens of the Government Decree, the mayor of the local government providing nursery and kindergarten ${ }^{2}$ may order an extraordinary break in the case of nursery and kindergarten institutions from 16 March 2020. The mayor shall inform the Minister of Human Resources of ordering the break. According to the government decree, domestic kindergartens could not accept children, they had to suspend their educational activities for an indefinite period (The Hungarian Government, 2020a).

The regulation has put early childhood institutions and stakeholders in an unprecedented, unexpected situation. In the new situation, central, uniform measures did not help the institutions concerned, according to the government decree, the maintainers ordered the institutions to do noneducational work and then to do home office work for their employees. Families were particularly weighed down by the situation, with some parents continuing to work from home in a home office, while others lost their jobs. In addition, they had to solve the care of younger children without institutional support and help digital education for school-age children. The placement of the child during the day, while the parent is working, is a vital issue for parents, regardless of social affiliation, and a basic function of the institution.

\footnotetext{
2 In English we use the word "kindergarten", those who work there are the "kindergarten pedagogue", or "early childhood educators", that can be used for both genders. These are according to the Hungarian approach to Kindergarten. According to the same approach, in Hungary, the phrase "preschool" is not correct as it does not mirror the local specialties of this field of science. Samely, the pedagogue who works there are not at all "preschool teachers" as not even Kindergarten pedagogues call themselves teachers as they do not teach in a direct and controlled way in the Kindergarten. Kindergarten workers deal with children 3-6, school starts at the age of 6 in Hungary.
} 
In the crisis caused by the virus, the relationship with the kindergarten was severed to a large extent. In Hungary, the number of disadvantaged children is high in public education institutions, contact with their families is inherently more difficult and research proves that disadvantaged parents prefer a personal, trusting relationship with the early childhood educators (Vargáné Nagy \& Molnár, 2017). There were disadvantaged areas where the head of the kindergarten visited the families personally and informed them of the emergency and the closure of the institution, as they sometimes did not have even a telephone.

In state-run, municipal kindergartens, the employer envisaged digital work for kindergarten pedagogues in kindergartens, similar to public education institutions (schools), in order to ensure that employees' work was justified and thus paid. Changed employment rules were declared in Government Decree 47/2020 (The Hungarian Government, 2020b). Educators either visited the institution regularly or kept in touch with parents from home. They had to perform the work tasks set out in the document regulating the operation of the institution and had to certify the work from home with a weekly report to the maintainer.

Families were hard hit by the regulation, as they had to take care of their children overnight, knowing that the possible illness of the older generation could easily be caused by the reorganization of childcare within the family and at the same time transforming their lives. After the changeover, the need for support for children's personal development at home required reconsideration (Balogh \& Szerepi, 2020).

Teleworking was a completely unknown concept for kindergarten pedagogues. Their work includes a loving reception of children, physical contact, hugging, and daily verbal contact with parents. This was replaced by an Information Technology (IT) tool that required a completely different form of communication and competencies. In general, kindergartens are not well equipped with Information and Communications Technology (ICT) tools either. The ability of kindergarten pedagogues to innovate has brought forward innovative efforts and the use of ICT tools, although a video, audio file or PowerPoint presentation cannot replace personal contact. Embrace, kind words, facial expressions and gestures, nonverbal gestures for children who understand speech even less, group cohesion cannot be replaced by such means.

It has become common practice for kindergartens to create closed Facebook groups to reach parents. Knowing the development level of the children and the kindergarten group, the parents were mainly recommended offline, mobile home play activity forms and experience opportunities that can be performed together with the children. The methodological recommendations took into account the children's personality, interests and individual abilities. Thus, they wanted to provide online help to all parents using the ICT tools at their disposal. Their helpful intentions were to support parents with their pedagogical knowledge and ideas to help families spend the increased common time at home. This period created an opportunity for educators to strengthen their individual pedagogical competencies and to be professionally renewed. They told the children video tales, played with puppets, sang songs, said poems, and sent parents creative craft activity ideas and games that could be done at home. Game ideas that could be played together with the family were collected and passed on to parents. The pedagogues tried to smuggle mental health, situational games into the life of the group, thus helping to process and accept the experiences.

In the use of online distance education, kindergartens sought to uphold the principle of supporting parental education, which is also a cornerstone of the kindergarten's child image, so they supported parent's child-rearing with activity recommendations that were based on personal advice, common activities, experiences and memories (Balogh \& Szerepi, 2020). At the same time, based on parental feedback, it was also found that kindergarten pedagogues asked parents for tasks that could not be performed at home due to lacking conditions and specific tools and went beyond the abilities of a preschool child. Parents responded in several ways to the activity ideas offered by kindergarten teachers. There were those who were constantly active from the first minute, performed the requested tasks, and provided feedback to the educators. There were families who did not take advantage of the suggestions offered by the kindergarten due to IT tools or lack of interest, lack of time, digital education of the older, school-age sibling. The development of different level special needs children has also been pushed into the online 
space, the effectiveness of which cannot be compared to personal contact activities.

Parental digital access did not work in all cases. IT knowledge and access to digital tools are uneven. (Hungarian Central Statistical Office, 2021). It is irrelevant to talk about online help in disadvantaged regions where families do not have the tools that online education assumes. Most of the disadvantaged parents have a pre-paid electric meter, and towards the end of the month there is no more money to recharge, and there is no electricity for a few days. There is no digital device and no internet connection at all. The school children also received the lesson on paper and the parent was usually unable to help. Contact with parents was not limited to previously used working-hours contact. The parents needed the help and feedback of the kindergarten pedagogue in the late evening and many cases on the weekends as well.

Kindergarten pedagogues also helped each other online through professional renewal and exchange of methodological experiences through the use of kindergarten pedagogical professional community sites. With the consent of the maintainer, cleanliness packs were distributed to families in need to comply with hygiene rules that are of paramount importance in the fight against the pandemic. In the institution, they made decorations, scrapped, cleaned, and performed administrative tasks. In addition to these, textiles were repaired, bean bags were sewn, and they also helped to make face masks for the employees of the municipality and those working in health care. There were institutions where, according to the order of the maintainer, the tasks related to the renovation of the building were also performed by the pedagogues, e.g. fence painting, group room renovation, painting. Due to the pandemic, more families needed home help. There was an example of kindergarten staff helping social institution staff, e.g. post office, pharmacy or day-to-day shopping. The kindergarten nurses cleaned and disinfected the institutions.

In institutions that also have kitchens, kitchen workers packed cold food for children on a weekly basis. According to 1997. XXXI Act $\S 21-21$ / B on guardianship administration, it is necessary to provide institutional food provide for children. Children receiving regular child protection benefits received food free of charge, but could also be claimed by others for a fee. The home delivery of food for kindergarten and school-age children was coordinated by the kindergarten staff, at which time they had the opportunity to talk to the parents, as neither the nurse nor the family caregiver visited the families in the segregation at the time of closure.

According to 152/2020. Government Decree, the maintainers appointed kindergartens on duty in the settlements; during the extraordinary break, the mayor was obliged to organize day-care for children of nursery and kindergarten age. Day-care service was to be provided for children without an infectious disease whose parents or other legal representatives required it for work. According to the Regulation, the submission of a request for day-care service was not subject to any formalities and could therefore be submitted either by e-mail or by telephone. The parent had to declare in writing that the child did not suffer from an infectious disease. The municipality had to organize the day-care service in small groups, and a maximum of five children per group could be supervised (The Hungarian Government, 2020c).

On May 20 in 2020 a new government decree was published in the Hungarian Gazette. The 215/2020. Government Decree on the reopening of kindergartens and nurseries (The Hungarian Government, 2020d). Before reopening, institutions assessed families need for kindergarten care and asked them to declare their children's health status. Most families demanded kindergarten care.

The 2020/2021 school year has brought further changes in the lives of institutions raising young children. According to Government Decree 431/2020 on protection measures, no person other than those working there and children could enter the territory of the public education institution (The Hungarian Government, 2020e). From September, parents could not enter the institution, the nurses and pedagogical assistants accompanied the children from the entrance to the group rooms. The body temperature of children and adults entering the institution was measured and recorded, an entry record was introduced, and adults wore masks indoors. Kindergartens tried to protect the health of children and workers with this defence as well. In everyday life, it is difficult to follow a rule, so e.g. use the face mask as it makes speech comprehension difficult. Hand sanitisers were installed in several rooms of the kindergarten, and children were also taught how to use them. They pay attention to the frequent correct hand washing, as well as the 
cleanliness and disinfection of the institution. The nurses keep a cleaning record. Parents may enter the institution only in justified cases, respecting the rules. Parental meetings were cancelled, daily contact with parents was reduced, and was limited to a previously created Messenger group or phone.

According to Government Decree 431/2020 on the protection measures of the epidemiological preparedness period, the body temperature measurement of employees and children upon arrival became mandatory from 1 October 2020. In case of coronavirus infection or coronavirus involvement, only the Education Office could order an extraordinary break in the given institution (The Hungarian Government, 2020e).

According to 509/2020 Government Decree, among other things, it ordered regular examinations and screening suitable for the detection of SARS-CoV-2 coronavirus for educational employees working in educational institutions. It was organized by the capital and county government offices and it was done with an antigen rapid test capable of detecting the coronavirus in the order that was specified by the Operational Staff. Participation in the examination was voluntary (The Hungarian Government, 2020f).

The institutions have drawn up an epidemiological action plan (which is a constantly changing protocol according to the epidemiological situation), which contains epidemiological rules for workers and parents (parents do not enter the kindergarten building, all parents have filled in a declaration - only healthy children can come to kindergarten, COVID-19 in the family should be reported, fever and hand disinfection should be performed at the door, and the use of a mask in the open air on the premises of the institution is mandatory according to the current government decree). Parents are still exercising their right not to require kindergarten for their child due to the virus.

Another difficulty was the illness of kindergarten pedagogues and kindergarten workers (nurses, pedagogical assistants). The continuous operation of the kindergarten in these cases requires great organization and perseverance. The situation caused by the COVID 19 virus has transformed the relationship system of the family institution. In the crisis caused by the virus, the parents' direct contact with the kindergarten daily was broken. The basic availability of institutional education for families has become uncertain. This faltering relationship affected both middle-class families, where the parents worked in the home office and disadvantaged families, for whom institutional education also played a complementary, mitigating role for children. Parents' IT skills, their resources and their attitudes towards educational institutions are not uniform either. In general, a traditionally well-functioning familykindergarten partnership is not benefited by the fact that parents cannot enter the institution, just as a child's community life is not well affected if the parent does not take him or her to kindergarten. In the case of effective communication with parents, the moments of personal encounters are appreciated. The situation caused by the virus has also greatly contributed to raising awareness of the importance of healthy lifestyle education from the areas of kindergarten education among parents and children. Adherence to security measures requires self-discipline.

This period was a serious burden for parents with small children. The consequences of the virus (loss of parents' jobs, difficulties in working from home, difficulties in placing and caring for a child, difficulties in digital education of a primary school child, hopeless life situation, insecurity, stress, difficulty in contacting grandparents, relatives, friends) made life difficult for families. In the case of children, another disadvantage was the lack of living conditions at home, play equipment, drawing tools and parental competence. The development of children with different developmental stages and delayed development (various movement developments, special pedagogical developments, etc.) has also been pushed into the online space, the disadvantages and consequences of which are not even measurable.

Educators were mentally and psychologically overwhelmed, everyone experienced the pandemic, insecurity, hopelessness and fear of illness differently. Kindergarten pedagogues said their IT skills have increased significantly since the outbreak began. This was mostly through autonomous learning and they have consciously updated their methodological knowledge adapted to the given situation and they have done professional renewal. 
Policies and practices of early childhood education and care during the COVID-19...

In the case of educators, the long-term effects include the move towards the digitization of documentation, and further training and conferences can also be extended to the online space in a costeffective way. The consequences of the situation caused by the COVID-19 virus and its long-term effects on the situation of families and ECEC institutions will be investigated later. The impact of the pandemic situation on out-of-institution education requires new pedagogical competencies. Communication between parents and kindergarten pedagogues is changing, and effective forms of help that can be provided online are becoming more valuable. The consequences for children's social relationships, development of speech and movement skills, and mental health are still unpredictable.

\section{Spain: Policies and Practices of ECEC during the COVID-19 Pandemic}

ECEC is essential to promote positive long-term learning outcomes (Paz-Albo, Cvencek, Herranz, Hervás, \& Meltzoff, 2017), as well as children's cognitive, language and social development in both the short- and long-term (Melhuish et al., 2015), but not all children have an opportunity to enjoy early experiences. In Spain, increasing children's participation in ECEC provides early access to learning experiences across the country, but these experiences differ depending on each region. In fact, Spain has implemented national and regional reforms in ECEC to enhance the educational needs of 0- to 6-year-old children, fuelling debate about the nature of ECEC and, specifically on the significance of the provision for children under the age of three. Moreover, Spain has one of the highest enrolment rates of 3-5-year-olds (97\%) in ECEC across Organisation for Economic Co-operation and Development [OECD] countries, and higher for children under the age of $3(36 \%)$, compared to $26 \%$ of the OECD average (OECD, 2019).

This situation is the result of the expansion of ECEC services in Spain. However, over the last decade, the childcare provision has experienced a surge of policy attention in Spain, as improving quality in the ECEC sector is a priority (Paz-Albo, 2018). In fact, the provision of ECEC in Spain has a regulatory framework established at the national level in which the purpose of ECEC is established as to contribute to the physical, emotional, social, and intellectual development of children (Orden ECI/3960/2007, 2008). However, the COVID-19 pandemic has an impact on how ECEC is organized and a variety of resources has been used to support children's learning.

By the middle of March 2020, ECEC institutions closures had been implemented across Spain. During the lockdown the Aprendo en casa (Learning at home) and Recursos para el aprendizaje en línea (Resources for online learning) educational sites were designed by the Spanish Ministry of Education and Vocational Training in order to provide educators, students and families access to online resources, materials and educational apps designed specifically for 0-6-year-olds and beyond. These resources supported learning continuity during the full school closures, stimulating curiosity and creativity to enhance learning, and strengthening learning through play and reading in addition to promoting autonomy, key aspects of ECEC in Spain. Furthermore, since the onset of the COVID-19 pandemic, Spain supported remote learning and offered guidance for parents in supporting learning for their children at home since every child is entitled to an education (Celaá, 2020).

After the lockdown, many children in ECEC started to return to in-person learning as the government encouraged schools to reopen buildings adopting several educational measures (see Orden $\mathrm{EFP} / 561 / 2020,2020$ ). In fact, all 0-3-year-olds were required to return to in-person learning to start the new school year in September 2020, while complying with the preventive, hygiene and health regulations established by the Spanish Ministry of Health. However, to secure support the reopening of schools for onsite learning 3-6-year-olds returned to school a few weeks later to be taught in small group bubbles for social distancing purposes. Within the ECEC context, this means reducing contact between groups of children and maintaining a safe distance of 1.5 meters. With regard to these policies and practices, the Interterritorial Council of the Spanish Health System (2020) admitted that respecting the social safe distance was harder for younger children and, also, that it was difficult to ensure their proper use of the masks for a long time. On the other hand, these children needed greater interaction and closeness in order to ensure successful development and to accomplish the proposed educational goals. 
Bearing in mind the particularities and needs of the ECEC years, the establishment of stable coexistence groups was proposed as the best alternative to solve the situation. These groups were made up of a reduced number of students and a tutor; ideally, with a maximum of 15 children and, if necessary, a maximum of 20. However, the maximum number of students might be settled by the Department of Education of each Autonomous Community with the permission of corresponding public health authorities. Following the instructions published by the Spanish Ministry of Health (2021), when a case of COVID-19 was detected, the students and tutor belonging to the stable coexistence group were considered as close contacts and, consequently, all of them must comply with the quarantine (10 days after the last contact with the confirmed case).

With the return to in-person learning, concerns arose from families and educators about the possibility that children were carriers of the disease and, consequently, the potential increase of COVID-19 cases. However, the situation of ECEC centres and educational institutions was positive, with just $0.73 \%$ of the groups temporary closed by the end of September (RTVE Noticias, 2020). In this sense, the preventive, hygiene and health measures (ventilation of classrooms, hand washing, stable coexistence groups, social distance, etc.) have permitted in-person learning as the educational approach mainly used at the present academic year. In fact, nowadays (about the end of the academic year), the data has confirmed that the Spanish ECEC and educational centres are safe spaces: $99.6 \%$ of the classrooms are open, whereas only $0.4 \%$ are in quarantine due to the COVID-19 pandemic, according to the data provided by the autonomous communities to the Ministry of Education (Spanish Ministry of Education and Vocational Training, 2021).

Despite the low percentage of groups temporarily closed for the COVID-19, KSNET and Spanish UNICEF (2020) have published the results of a survey showing that $86 \%$ of the Spanish entities affirm that children have suffered difficulties to continue with the academic year. According to this study, the main obstacles have been the digital gap, the lack of space to study at home, and the absence of accompaniment (KSNET \& Spanish UNICEF, 2020). Apart from the academic consequences, several studies with Spanish population have pointed that the lockdown has hampered children's development, including negative consequences in their physical health (Valero, Martín, Domínguez-Rodríguez \& Grupo Confisalud, 2020), an increment on sedentary time (Alonso-Martínez, Ramírez-Vélez, García-Alonso, Izquierdo \& GarcíaHermoso, 2021; Arufe-Giráldez, Sanmiguel-Rodríguez, Zagalaz-Sánchez, Cachón-Zagalaz \& GonzálezValero, 2020), and an exacerbation of their internalizing and externalizing problems (Alonso-Martínez et al., 2021).

In this line, we cannot forget that, although it seems that the worst scenario of the COVID-19 pandemic has passed, ECEC will be crucial to overcoming the aforementioned negative effects of the lockdown and social distance measures. As it has been pointed, educational and care institutions not only promote physical activities, appropriate diet, and good sleep habits (Brazendale et al., 2017) which, in turn, might help to mitigate the negative effects of the COVID-19 pandemic in children's development, but also Spanish ECEC centres might play a critical role providing safe environments to children to be able to interact with peers and teachers, and develop their socioemotional skills.

\section{Turkey: Policies and Practices of ECEC during the COVID-19 Pandemic}

In many countries, including Turkey, one of the precautions taken to prevent the spread of COVID19 has been the closure of schools and other educational institutions. On February 3, 2020, more than five weeks before the first COVID-19 case was detected in Turkey, a pamphlet titled Coronavirus Information Note had been prepared for Turkish children and parents, detailing some precautions that had to be taken to prevent the virus from entering the country (Ministry of National Education [MoNE], 2020a). It also mentioned ways to prevent respiratory tract infections and described the correct hand-washing procedure to be followed by children in ECEC institutions.

Soon after the detection of the first COVID-19 case in Turkey, on March 11, 2020, schools across the country were closed for two weeks, i.e., from March 16 to March 30 (MoNE, 2020b). During that period, on March 23, Educational Informatics Network run by the Turkish Radio and Television Corporation (TRT), 
Policies and practices of early childhood education and care during the COVID-19...

known as EBA TV, started broadcasting to the primary, secondary and high schools in cooperation with MoNE and TRT (MoNE, n.d.). However, no channels or broadcasts appear to have been aimed at ECEC children at that time.

At the beginning of the following month, a program for parents named Bizden (literally 'from us') was launched on EBA TV to provide effective role models for child development during the distanceeducation process, alongside practical information about that process (MoNE, 2020c). The show's underlying purpose appears to have been to encourage parents to deal with their young children more consciously (Sak, Şahin-Sak, \& Nas, 2020).

During the ensuing extraordinary time that parents spent at home with their children, a printed set of daily-activity recommendations titled Distance Education, Close Interest was prepared and shared with parents to guide them in establishing close relationships and strong ties with their children. The guide was aimed at families with children of up to secondary-school age, and its core message was "in this process, we are with you and close to you. We will survive together" (MoNE, 2020d). Then, another guidebook titled Play in Crisis (MoNE, 2020e), emphasizing the importance of play and how families could contribute to it was added to the same series.

Based on recommendations from the Turkish government's Scientific Committee at the end of April 2020, it was decided that distance education would continue until May 31, 2020 (MoNE, 2020f). During this latter period of homeschooling, MoNE (2020g) recommended that parents and their children play three games together, called "And Walk Like This", "Tell Me About Me" and "Don't Step on Paper". Additionally, at the beginning of May 2020, Turkey's General Directorate of Special Education and Guidance Services published a booklet titled Elif and Alp. This publication featured activities aimed at helping ECEC and primary-school children adapt to pandemic conditions and lockdown by ensuring that they understood and expressed their feelings (MoNE, 2020h).

At the end of May 2020, as part of a planned easing of lockdown, it was announced that nurseries and daycare centres would until further notice only serve households where all parents/carers had returned to working outside the home (Resmi Gazete, 2020). Subsequently, as the implementation of precautions had proved successful throughout the country, the normalization process continued as planned. Therefore, the General Directorate of Private Education Institutions circulated a letter authorizing private ECEC institutions to reopen beginning on June 1, 2020, if requested by their heads and the parents of the children. A similar official letter was also then sent to public ECEC institutions by MoNE, though in this case, it was not school heads but the Education Directorate of each of the nation's provinces that had to make the request, again with parental consent. All public and private ECEC institutions that reopened were required to observe strict COVID-19 safety rules, including the wearing of medical masks, hand hygiene, and social distancing (MoNE, 2020i).

In September 2020, schools that had been closed March 2020 due to the pandemic were opened to ECEC children and first graders. During the first week of school, which was September 21-25, 2020 in all regions, a one-day face-to-face education orientation program for these children was implemented. In ECEC settings, the orientation week consisted of a single day featuring five 30-minute activities, expanding in the second week to two days, with the same number and length of activities (MoNE, 2020j). After the resumption of face-to-face schooling, the MoNE released Contactless Play Book (Erdoğan, 2020), as a fun means of helping ECEC children and primary-school students internalize the wearing of masks, social distancing, and personal-hygiene rules, and more generally, adapt to the 'new normal' way of doing things. The book's 60 games covered skills such as meeting someone, communication, attention, movement and cooperation, none involving any physical contact (MoNE, 2020j).

October 12, 2020, marked the start of the second stage of face-to-face education in Turkish schools, in which the two-day weekly education process that had been implemented in ECEC institutions in September 2020 was increased to five days (MoNE, 2020k). Then, beginning in December, TRT-EBA Kindergarten was broadcast on EBA TV's Primary School channel every weekday at 8:00 a.m., and 7:30 p.m. Its original content was divided into three sections: "Calendar", "Activity Zone" and "As a Family". 
"Calendar" was aimed at helping children start the day as if they were already at school, and thus explained concepts including dates, seasons, days of the week, colours and shapes. In "Activity Zone", ECEC teachers conducted Turkish-language, math, science, music, drama, art and play activities, relying on many a wide range of materials, toys and visual documents in line with the MoNE-approved preschool curriculum. Lastly, the "As a Family" section provided important advice to parents of ECEC children, including what should be considered when communicating with their children, domestic rules, and personalitydevelopment processes (TRTHaber, 2020).

Due to an increase in the number of coronavirus cases in Turkey, a new weekend lockdown was enforced in December 2020, and ECEC institutions were again closed (Ministry of Interior, 2020). In a press release dated March 1, 2021, MoNE (2021a) also announced that, based on decisions made in a recent meeting of the Presidential Cabinet, face-to-face education would resume the following day in all ECEC institutions, primary schools, and 8th and 12th-grade classrooms across the country. The plan was to restart face-to-face education in all ECEC institutions on a full-time basis, both in provinces defined as at low/medium coronavirus risk and those defined as at high/very high risk. Via press releases on March 29 and April 13, MoNE (2021b, 2021c) announced changes to practices at various educational levels but confirmed that face-to-face full-time education would continue in ECEC institutions.

In line with decisions made in the Presidential Cabinet on April 26, the whole of Turkey is - at the time of writing - in a three-week period of strict lockdown, expected to end on May 17 (Ministry of Interior, 2021). In this context, face-to-face education has been suspended in all institutions, and distance education has resumed (MoNE, 2021d). Also, in a press release dated May 12, 2021, it was announced that distance education might continue after the lifting of the lockdown per se, with the decision about that to be made on May 17 (MoNE, 2021e).

Unsurprisingly, given these circumstances, pandemic conditions - and especially lockdowns - have been a challenging experience for ECEC children. They have become more aggressive and anxious and exhibited more misbehaviour. Negative effects on children of spending lengthy periods looking at TV screens and mobile devices have also emerged (Toran, Sak, Xu, Şahin-Sak, \& Yu, 2021). That being said, however, activities conducted by teachers through eba.gov.tr have become very important to young children, and some of them have been effective educationally. It has also been noted that many parents organized various activities for and with their children, in line with their teachers' recommendations, which as well as boosting the children's sense of well-being enabled them to continue preparing for primary school (Duran \& Ömeroğlu, 2020). However, it has also been argued that distance education has not been effective enough for either ECEC children or primary-school students (Demir Öztürk, Kuru, \& Demir Yıldız, 2020). This is thought to be related to their ages, as children in these years still have difficulty using distance-education tools and other technology on their own. Similarly, play and hands-on activities that are effective in supporting young children's learning are not easy online (Kim, 2020). In short, children of primary age and below appear to only benefit from distance education if under close supervision by their parents or other adults. Thus, in cases where the relevant adults' willingness or ability to offer such supervision is low, young children cannot make efficient use of the EBA portal or other popular educational applications such as Zoom (Sak et al., 2020).

\section{Conclusion}

The COVID-19 pandemic, which has affected all life on a global scale, has caused the reorganization of all areas of life. Although emergency policies were developed against the pandemic at first, it can be said that more effective policies were developed with a better understanding of the pandemic over time. At the first stage of the pandemic, schools were closed worldwide, and then distance education started with the emergency solutions developed later on. For more than a year, education has been tried to be continued with distance or hybrid (online and face-to-face) teaching models all over the world. Nevertheless, policies developed in the field of ECEC differed among countries, and this situation prevented the development of a standard in education. This review article focused on the policies developed for ECEC, the situation of children, teachers, and families during the COVID-19 pandemic in the countries (Australia, Croatia, 
Policies and practices of early childhood education and care during the COVID-19...

Hungary, Spain, and Turkey) included in this article.

The countries which faced the pandemic have managed ECEC differently. The reasons for this difference are the importance given to early childhood education and the resources allocated. Although schools were closed at first due to the pandemic, some countries provided resources and support for the sustainability of education. However, it has been observed that there are countries where early childhood education is ignored when compared to the other educational levels. Especially countries with insufficient technological infrastructure have left the distance education process of children mostly to the competence of teachers and the capacity of accessible digital tools. It has been stated that the groups most negatively affected by this process are disadvantaged groups and that these groups have very limited access to education and teachers.

Although the COVID-19 pandemic directly affected adults as a disease, the measures such as the closure of schools and the quarantines directly affected children negatively. For instance, the time children spent in front of screen has increased, their movement area has been limited, and the home environment has been insufficient in supporting children's development. In countries where face-to-face education was started during the pandemic, children were expected to comply with the measures taken against the pandemic and the protocols that were prepared. However, radical changes in the educational environment and materials along with the reduction of class sizes made it difficult for children to adapt to the process.

While discussions about how education can be continued with the pandemic, the importance of teachers' role in education has brought teachers to the fore. In this process, it can be said that teachers show a great effort to reach children and make education sustainable. In some countries, teachers were supported to use and access digital tools, while in others this was ignored. In other words, it has been seen that teachers try to continue the education with their professional competence and the digital tools and applications they can access. The COVID-19 pandemic has also brought up the discussion of teacher education to provide professional competencies in preparation for possible crises.

The COVID-19 pandemic, which directly affects social life, has caused radical changes, especially in the lives of families with children. The interruption of children's school life has left the responsibilities of education and care to the parents. The parents who had to work from home tried to take on their children's education and care responsibilities in coordination with the teacher. However, disadvantaged families had difficulties in carrying out their child's education and care due to the interruption of social support opportunities. During this process, parents have experienced serious economic, social, and psychological difficulties. In addition, the fact that the responsibility of children's education and care is mostly undertaken by mothers has made invisible gender inequalities visible.

As a result, the COVID-19 pandemic has revealed that we need to focus on eliminating educational inequalities, placing policies for the welfare of children on more realistic foundations, rebuilding teacher education, and improving the welfare of families. Priorizating the best interests of the child in the policies to be developed and building the social ecology on justice will ease overcoming the crises that will be faced.

\section{Declarations}

Acknowledgements: The production and dissemination of knowledge in the public interest are among the founding purposes of the Journal of Childhood, Education \& Society. For this purpose, editor in chief invited all editorial board members to write a review article about the COVID-19 pandemic in the scope of the JCES. This review article was written by editorial board members who responded to the invitation in line with the founding purposes. The countries, in this review article, are ordered alphabetical.

Authors' contributions: Adrijana Visnjic-Jevtic wrote Croatia, Anikó Varga Nagy wrote Hungary, Gulsah Ozturk wrote Australia, İkbal Tuba Şahin-Sak wrote Turkey, Jesús Paz-Albo and Noelia Sánchez-Pérez wrote Spain, and Mehmet Toran designed the paper, wrote abstract, introduction and conclusion part. The authors of this review article are ordered alphabetical. All authors have read, provided feedback and approved the final submission.

Competing interests: The authors declare that they have no competing interests.

Funding: No funding was provided for this study. 
Adrijana VISNJIC-JEVTIC et al.

\section{References}

Act 31 of 1997 (Hungarian Child Protection Act). Retrieved from thttps://eige.europa.eu/gender-basedviolence/resources/hungary/act-31-1997-hungarian-child-protection-act

Alonso-Martínez, A. M., Ramírez-Vélez, R., García-Alonso, Y., Izquierdo, M., \& García-Hermoso, A. (2021). Physical activity, sedentary behavior, sleep and self-regulation in Spanish preschoolers during the COVID-19 lockdown. International Journal of Environmental Research and Public Health, 18(2), 693. https://doi.org/10.3390/ijerph18020693

Anderson, D. R., \& Subrahmanyam, K. (2017). Digital screen media and cognitive development. Pediatrics, 140 (Supplement 2), 57-61. https://doi.org/10.1542/peds.2016-1758C

Arufe-Giráldez, V., Sanmiguel-Rodríguez, A., Zagalaz-Sánchez, M. L., Cachón-Zagalaz, J., \& González-Valero, G. (2020). Sleep, physical activity and screens in 0-4 years Spanish children during the COVID-19 pandemic: Were the WHO recommendations met? Journal of Human Sport and Exercise. https://doi.org/10.14198/jhse.2022.173.02

Balogh, B., \& Szerepi, S. (2020). A család és az óvoda nevelési funkcióinak összhangja a COVID-19 vírus okozta rendkivüli helyzet tükrében. In V. Nagy Anikó (Eds.), Családi nevelés. nevelési problémák a családban (pp.7-17). Debrecen: Didakt Kiadó.

Brazendale, K., Beets, M. W., Weaver, R. G., Pate, R. R., Turner-McGrievy, G. M., Kaczynski, A. T., ... von Hippel, P. T. (2017). Understanding differences between summer vs. school obesogenic behaviors of children: The structured days hypothesis. International Journal of Behavioral Nutrition and Physical Activity, 14(1), 1-14. https://doi.org/10.1186/s12966-017-0555-2

Celaá, I. (2020). Aprendo en casa: Carta de la ministra. Aprendo en casa. Retrieved from https://aprendoencasa.educacion.es/carta-de-laministra

Demir Öztürk, E., Kuru, G., \& Demir Yıldız, C. (2020). Covid-19 pandemi günlerinde anneler ne düşünür, çocuklar ne ister? Anne ve çocuklarının pandemi algısı. Avrasya Sosyal ve Ekonomi Araştırmaları Dergisi, 7(5), 204-220.

Department of Education, Skills and Employment (2020a). Child care in Australia report December quarter 2020. Canberra, ACT: Australian Government. Retrieved from https://www.dese.gov.au/key-official-documents-about-early-childhood/earlychildhood-and-child-care-reports/child-care-australia/child-care-australia-report-december-quarter-2020

Department of Education, Skills and Employment (2020b). Recovery package for early childhood education and care sector. Retrieved from https://www.dese.gov.au/covid-19/childcare/recovery-package-early-childhood-education-and-care-sector. https://www.dese.gov.au/covid-19/childcare/recovery-package-early-childhood-education-and-care-sector

Department of Health (2021). Coronavirus (COVID-19) current situation and case numbers. Australian Government. Retrieved from https://www.health.gov.au/news/health-alerts/novel-coronavirus-2019-ncov-health-alert/coronavirus-covid-19-currentsituation-and-case-numbers\#local-outbreak-information

Duran, A., \& Ömeroğlu, E. (2020). COVID-19 pandemi sürecinde ebeveynlerin okul öncesi dönemdeki çocukları ile iletişimlerine ilişkin görüşleri. In S. Thakur \& A. Yadav (Eds.), International conference on COVID-19 studies (pp.428-436). IKSAD Publishing House.

Early Childhood Australia. (2020). ECA response: COVID-19. Canberra, ACT: Early Childhood Australia Retrieved from http://www.earlychildhoodaustralia.org.au/wp-content/uploads/2020/05/COVID-19-ECEC-Health-and-Hygiene-MembersSummary_UPDATE_29052020_Typeset.pdf

Erdoğan, T. (2020). Temassız oyunlar. Ankara: Milli Eğitim Müdürlüğü. Retrieved from http://cdn.eba.gov.tr/kitap/temassizoyunlar/\#p=3

Hungarian Central Statistical Office. (2021, April 10). Data on the Coronavirus Pandemic. Retrieved from https://www.ksh.hu/apps/shop.lista?p lang=HU\&p temakor kod=ON\&p kapcsolodo=ikt

Interterritorial Council of the National Health System. (2020, August 27). Acuerdo del Consejo Interterritorial del Sistema Nacional de Salud, adoptado en coordinación con la conferencia sectorial de Educación, sobre la declaración de actuaciones en salud pública frente al COVID-19 para centros educativos durante el curso 2021-21. Retrieved from https://www.lamoncloa.gob.es/serviciosdeprensa/notasprensa/educacion/Documents/2020/27082020 Acuerdo.pdf

Kim, J. (2020). Learning and teaching online during Covid-19: Experiences of student teachers in an early childhood education practicum. International Journal of Early Childhood, 52(2), 145-158. https://doi.org/10.1007/s13158-020-00272-6

KSNET \& Spanish UNICEF (2020). Impacto de la crisis por COVID-19 sobre los niños y niñas más vulnerables: Reimaginar la reconstrucción en clave de derechos de infancia. UNICEF. Retrieved from https://www.unicef.es/sites/unicef.es/files/recursos/informe-infacia-covid/covid19-infancia vulnerable unicef.pdf

Lee, I. (2021). Crisis of care and education in the early years: Paradoxical moments in the global pandemic. Global Studies of Childhood, 10(4), 385-394. https://doi.org/10.1177/2043610620978491

Marshall, S.J., Biddle, S.J., Gorely, T., Cameron, N., \& Murdey, I. (2004). Relationships between media use, body fatness and physical activity in children and youth: A meta-analysis. International Journal of Obesity, 28(10), $1238-1246$. https://doi.org/10.1038/sj.ijo.0802706 
Policies and practices of early childhood education and care during the COVID-19...

McAnulty, J., \& Ward, K. (2020). Suppressing the epidemic in New South Wales. New England Journal of Medicine, 382(21), e74. https://doi.org/10.1056/NEJMc2011592

Melhuish, E., Ereky, S., Petrogiannis, K., Ariescu, A., Penderi, E., Rentzou, K., ... Broekhuisen, P. (2015). A review of research on the effects of Early Childhood Education and Care (ECEC) upon child development. CARE project; Curriculum Quality Analysis and Impact Review of European Early Childhood Education and Care (ECEC). European Commission.

Mendelsohn, A. L., Brockmeyer, C. A., Dreyer, B. P., Fierman, A. H., Berkule Silberman, S. B., \& Tomopoulos, S. (2010). Do verbal interactions with infants during electronic media exposure mitigate adverse impacts on their language development as toddlers?. Infant \& Child Development, 19(6), 577-593. https://doi.org/10.1002/icd.711

Ministarstvo Znanosti i Obrazovanja. (2020). Preporuke za rad s djecom rane i predškolske dobi u dječjim vrtićima. Ministarstvo Znanosti i Obrazovanja Republike Hrvatske.

Ministarstvo Znanosti, Obrazovanja i Sporta. (2015). Nacionalni kurikulum ranog i predškolskog odgoja i obrazovanja Republike Hrvatske. Narodne novine 5/15.

Ministry of Interior. (2020). Koronavirüs ile mücadele kapsaminda-yeni kısitlama ve tedbirler genelgeleri. Retrieved from https://www.icisleri.gov.tr/koronavirus-ile-mucadele-kapsaminda-sokaga-cikma-kisitlamalari---yeni-kisitlama-ve-tedbirlergenelgeleri

Ministry of Interior. (2021). 81 il valiliğine tam kapanma tedbirleri genelgesi gönderildi. Retrieved from https://www.icisleri.gov.tr/81-ilvaliligine-tam-kapanma-tedbirleri-genelgesi-gonderildi

Ministry of National Education. (2020a). Yeni Koronavirüs (2019-ncCoV). Retrieved from http://www.meb.gov.tr/meb_iys_dosyalar/2020_02/04162145_2019_nCoV_brosur.pdf

Ministry of National Education. (2020b). Bakan Selçuk, Koronavirüs'e karşı eğitim alanında alınan tedbirleri açıladı. Retrieved from http://www.meb.gov.tr/bakan-selcuk-koronaviruse-karsi-egitim-alaninda-alinan-tedbirleri-acikladi/haber/20497/tr

Ministry of National Education. (2020c). TRT EBA TV'de BİZDEN adlı veli kuşă̆ı programı yayınlanacak. Retrieved from https://ikieylul.meb.k12.tr/icerikler/trt-eba-tvde-bizden-adli-veli-kusagi-programi-yayinlanacak 9533968.html

Ministry of National Education. (2020d). Okul öncesi, 1-8. sinfflar: Uzaktan eğitim yakından ilgi. Retrieved from http://www.meb.gov.tr/meb iys dosyalar/2020 04/15142822 UzaktanEgitimYakYndanYlgi.pdf

Ministry of National Education. (2020). Kriz durumunda oyun. Retrieved from http://www.meb.gov.tr/meb_iys_dosyalar/2020_04/17111243_kriz_durumunda_oyun.pdf

Ministry of National Education. (2020f). Uzaktan eğitim 31 Mayıs 2020 tarihine kadar uzatıldı. Retrieved from https://ihsangaziio.meb.k12.tr/icerikler/uzaktan-egitim-31-mayis-2020-tarihine-kadar-uzatildi 9614361.html

Ministry of National Education. (2020g). Çocuklar için üç oyun. Retrieved from http://www.meb.gov.tr/meb iys dosyalar/2020 05/01165813 oyun.jpg

Ministry of National Education. (2020h). Elif ile Alp: Çocuklar için psikoeğitsel etkinlikler. Retrieved from https://orgm.meb.gov.tr/meb iys dosyalar/2020 05/02012900 cocuk kitabi2.pdf

Ministry of National Education. (2020i). Resmi okul öncesi kurumlar 19 Haziran'a kadar hizmet. Retrieved from http://www.meb.gov.tr/resmi-okul-oncesi-kurumlari-19-hazirana-kadar-hizmet-sunabilecek/haber/21042/tr

Ministry of National Education. (2020j). Yüz yüze eğitim, anasınıfı ve ilkokul 1'inci sınıflarda başladı. Retrieved from https://www.meb.gov.tr/yuz-yuze-egitim-anasinifi-ve-ilkokul-1inci-siniflarda-basladi/haber/21672/tr

Ministry of National Education. (2020k). Okullarda yüz yüze eğitimde ikinci aşama 12 Ekim Pazartesi günü başlyyor. Retrieved from https://www.meb.gov.tr/okullarda-yuz-yuze-egitimde-ikinci-asama-12-ekim-pazartesi-gunu-basliyor/haber/21776/tr

Ministry of National Education. (2021a). Basın açıklaması: Ĕ̆itimde kontrollü normalleşme sürecinde eğitim kurumlarının açılma ve uygulama kriterleri. Retrieved from https://www.meb.gov.tr/basin-aciklamasi-egitimde-kontrollu-normallesme-surecinde-egitimkurumlarinin-acilma-ve-uygulama-kriterleri/haber/22651/tr

Ministry of National Education. (2021b). Basın açılaması. Retrieved from https://www.meb.gov.tr/basin-aciklamasi/haber/22900/tr

Ministry of National Education. (2021c). Basın açıklaması. Retrieved from https://www.meb.gov.tr/basin-aciklamasi/haber/23005/tr

Ministry of National Education. (2021d). Basın açıklaması. Retrieved from https://www.meb.gov.tr/basin-aciklamasi/haber/23092/tr

Ministry of National Education. (2021e). Basın açıklaması: Yüz yüze ve uzaktan eğitim. Retrieved from https://www.meb.gov.tr/basinaciklamasi-yuz-yuze-ve-uzaktan-egitim/haber/23197/tr

Ministry of National Education. (n.d.). TRT EBA TV [Turkish Radio and Television Corporation-Educational Informatics Network]. Retrieved from http://covid19.meb.gov.tr/covid19.html? catNo=7 


\section{Adrijana VISNJIC-JEVTIC et al.}

Orden ECI/3960/2007, de 19 de diciembre, por la que se establece el currículo y se regula la ordenación de la educación infantil. (2008). Boletín Oficial del Estado, 5, de 5 de enero de 2008, pp. 1016-1036. https://www.boe.es/boe/dias/2008/01/05/pdfs/A0101601036.pdf

Orden EFP/561/2020, de 20 de junio, por la que se publican Acuerdos de la Conferencia Sectorial de Educación, para el inicio y el desarrollo del curso 2020-2021. Boletín Oficial del Estado, 175, de 24 de junio de 2020, pp. 44183-44187. https://www.boe.es/boe/dias/2020/06/24/pdfs/BOE-A-2020-6685.pdf

Organisation for Economic Co-operation and Development. (2019). Education at a glance 2019: Country note, Spain. OECD Publishing: Paris. https://www.oecd.org/education/education-at-a-glance/EAG2019 CN ESP.pdf

Park, E., Logan, H., Zhang, L., Kamigaichi, N., \& Kulapichitr, U. (2020). Responses to coronavirus pandemic in early childhood services across five countries in the Asia-Pacific region: OMEP Policy Forum. International Journal of Early Childhood, 52, 249266. https://doi.org/10.1007/s13158-020-00278-0

Parliement of Australia (2020a). COVID-19 Economic response- free child care. Retrieved from https://www.aph.gov.au/About Parliament/Parliamentary Departments/Parliamentary Library/FlagPost/2020/April/Coron avirus_response-Free_child_care.

Parliement of Australia (27 March, 2020b). Transcript of Prime Minister's briefing. Retrieved from https://parlinfo.aph.gov.au/parlInfo/search/display/display.w3p;query=Id:\%22media/pressrel/7268032\%22

Parliement of Australia. (2014). Universal access to early childhood education: a quick guide. Retrieved from https://www.aph.gov.au/About Parliament/Parliamentary Departments/Parliamentary Library/pubs/rp/rp1314/QG/Child hoodEducatAccess

Paz-Albo, J. (2018). Enhancing the quality of early childhood education and care: ECEC tutors' perspectives of family engagement in Spain. Early Child Development and Care, 188(5), 613-623. https://doi.org/10.1080/03004430.2017.1417272

Paz-Albo, J., Cvencek, D., Herranz, C. V., Hervás, A., \& Meltzoff, A. N. (2017). Preschoolers' mathematical play and colour preferences: a new window into the development of gendered beliefs about math. Early Child Development and Care, 187(8), 1273-1283. https://doi.org/10.1080/03004430.2017.1295234

Radesky, J. S., Schumacher, J., \& Zuckerman, B. (2015). Mobile and interactive media use by young children: The good, the bad, and the unknown. Pediatrics, 135(1), 1-3. https://doi.org/10.1542/peds.2014-2251

Resmi Gazete. (2020). COVID-19 kapsamında kamu kurum ve kuruluşlarında normalleșme ve alınacak tedbirler. Retrieved from https://www.resmigazete.gov.tr/eskiler/2020/05/20200529M1-1.pdf

RTVE Noticias (2020, September 24). Más de 2800 aulas de toda España han tenido que cerrar desde que comenzó el curso. Retrieved from https://www.rtve.es/noticias/20200924/alrededor-2800-aulas-toda-espana-han-tenido-cerrar/2042918.shtml

Sak, R., Şahin-Sak, İ. T., \& Nas, E. (2020). Pandemi sürecinde okul öncesi eğitim. In F. Tanhan \& H. İ. Özok (Eds.), Pandemi ve eğitim (pp. 161-189). Ankara: An1.

Schmidt, M. E., Pempek, T. A., Kirkorian, H. L., Lund, A. F., \& Anderson, D. R. (2008). The effects of background television on the toy play behavior of very young children. Child Development, 79(4), 1137-1151. https://doi.org/10.1111/j.1467-8624.2008.01180.x

Setliff, A. E., \& Courage, M. L. (2011). Background television and infants' allocation of their attention during toy play. Infancy, 16(6), 611-639. https://doi.org/10.1111/j.1532-7078.2011.00070.x

Somolanji Tokić, I., \& Vukašinović, A. (2020). Continuity of educational process through virtual kındergarten during covid-19 outbreak - Case study from Croatia. In L. Gómez Chova, A. López Martínez, \& I. Candel Torres (Eds.), EDULEARN20 proceedings: 12th international conference on education and new learning technologies (pp. 7861-7870). IATED Academy https://doi.org/10.21125/edulearn.2020.1981

Spanish Ministry of Education and Vocational Training. (2021, March 29). El segundo trimestre del curso escolar concluye con el 99,6\% de aulas abiertas, gracias al esfuerzo continuo de la comunidad educativa. Retrieved from https://www.lamoncloa.gob.es/serviciosdeprensa/notasprensa/educacion/Paginas/2021/290321-aulas_abiertas.aspx

Spanish Ministry of Health. (2021). Guía de actuación ante la aparición de casos de COVID-19 en centros educativos (Documento técnico. Versión del 26 de febrero de 2021). Retrieved from https://www.educacionyfp.gob.es/dam/icr:2a9c2230-358d-4c6a-b1e1122c1a2b2234/guia-actuacion-centros-educativos.pdf

The Hungarian Government. (2020a). The Hungarian Government Decree 40/2020 (III. 11.) on the declaration of state of danger. Retrieved from https://ils.hu/storage/covid-19/en/Government\%20Decree\%2040-2020\%20(III.11.)\%20State\%20of\%20Danger.pdf

The Hungarian Government. (2020b). The Hungarian Government Decree 47/2020 (III. 18.) Retrieved from https://njt.hu/translated/doc//2020R0047K 20200319 FIN.pdf

The Hungarian Government. (2020c). The Hungarian Government Decree 152/2020. (IV. 27.) day care for children of nursery and kindergarten age. Retrieved from https://net.jogtar.hu/jogszabaly?docid=A2000152.KOR\&txtreferer=00000001.txt

The Hungarian Government. (2020d). The Hungarian Government Decree 215/2020 (V. 20.) Reopening of crèches, kindergartens. Retrieved 
Policies and practices of early childhood education and care during the COVID-19...

from https://uj.njt.hu/jogszabaly/2020-215-20-22

The Hungarian Government. (2020e). The Hungarian Government Decree 431/2020 (IX. 18) on protective measures during the period of state of epidemiological preparedness. Retrieved from http://jogszabalykereso.mhk.hu/translated/doc/I2020R0431K 20201104 FIN.pdf

The Hungarian Government. (2020f). The Hungarian Government Decree 509/2020 (XI. 19.) regular examinations and screening suitable for the detection of SARS-CoV-2 coronavirus for educational employees working in educational institutions. Retrieved from https://net.jogtar.hu/jogszabaly?docid=a2000509.kor

Thorpe, K., Staton, S., Houen, S., \& Beatton, T. (2020). Essential yet discounted: COVID-19 and the early childhood education workforce. Australian Educational Leader, 42(3), 18-21.

Toran, M., Sak, R., Xu, Y., Şahin-Sak, İ. T., \& Yu, Y. (2021). Parents and children during the COVID-19 quarantine process: Experiences from Turkey and China. Journal of Early Childhood Research, 19(1) 21-39. https://doi.org/10.1177/1476718X20977583

TRTHaber. (2020). TRT EBA Anaokulu yayın hayatına başladi. Retrieved from https://www.trthaber.com/haber/guncel/trt-ebaanaokulu-yayin-hayatina-basladi-540692.html

United Nations Children's Emergency Fund. (2021a). Pre-primary education. UNICEF. Retrieved from https://data.unicef.org/topic/education/pre-primary-education/

United Nations Children's Emergency Fund. (2021b). COVID-19 and children. UNICEF. Retrieved from https://data.unicef.org/covid19-and-children/

United Nations Children's Emergency Fund. (2021c). Education and COVID-19. UNICEF. Retrieved from https://data.unicef.org/topic/education/covid-19/\#status

United Nations Educational, Scientific and Cultural Organization. (2020). Startling digital divides in distance learning emerge. Paris: UNESCO. Retrieved from https://en.unesco.org/news/startling-digital-divides-distance-learning-emerge

United Nations Educational, Scientific and Cultural Organization. (2021). COVID-19 impact on education. Paris: UNESCO. Retrieved from https://en.unesco.org/covid19/educationresponse

Valero, E., Martín, U., Domínguez-Rodríguez, A., \& Grupo Confisalud (2020). Covid-19 y salud infantil: El confinamiento y su impacto según profesionales de la infancia. Revista Española de Salud Pública, 94, 1-7.

Vargáné Nagy, A., \& Molnár, B. (2017). Szerepelvárások és szerepértelmezések roma kulturális hátterü családokban. In A. Vargáné Nagy (Eds.), Családi nevelés. 2. (pp. 109-132). Debrecen: Didakt Kiadó.

Višnjić-Jevtić, A., \& Visković, I. (2021). Roditeljstvo u vrijeme pandemije Covid-19: perspektiva roditelja djece rane i predškolske dobi. Metodički ogledi, 28(1), 11-38.

Vlada Republike Hrvatske. (2020). Odluka o obustavi izvođenja nastave u visokim učilištima, srednjim i osnovnim školama te redovnog rada ustanova predškolskog odgoja $i$ obrazovanja $i$ uspostavi nastave na daljinu. Retrieved from https://narodnenovine.nn.hr/clanci/sluzbeni/2020_03_29_670.html

World Health Organization. (2020, 11 March). WHO Director-General's opening remarks at the media briefing on COVID-19. Retrieved from https://www.who.int/director-general/speeches/detail/who-director-general-s-opening-remarks-at-the-media-briefingon-covid-19---11-march-2020

Zimmerman, F.J., Christakis, D.A., \& Meltzoff, A.N. (2007). Associations between media viewing and language development in children under age 2 years. Journal of Pediatrics, 151, 364-368. https://doi.org/10.1016/j.jpeds.2007.04.071 